\title{
Urban tourism in Slovakia - its quantification, spatial differentiation and typification
}

\author{
Anton KasagrandaA, Eva RajčákováA , Jiří Vystoupil ${ }^{\mathrm{B}}$ \\ Received: February 29, 2016 | Revised: April 7, 2016 | Accepted: June 2, 2016
}

DOI: 10.18421/GP20.02-08

\begin{abstract}
Urban tourism, characterized by a high share of international tourists in Slovakia, represents the specific type of tourism that is the main aim of this study. It includes analysis of bed capacities of collective accommodation establishments and urban tourism performance, which represent the basis for the subsequent typification of urban tourism centres. In typification, localization conditions and their attractiveness, which form the very basis of potential of urban tourism centres, are evaluated. Results of the research indicate, that urban tourism is one of the most important type of tourism in Slovakia. In the terms of tourism, the most valuable towns are those with high cultural and historical value (historical towns) and towns defined as spa resorts. The main objective of this paper is the quantification and spatial interpretation of urban tourism in Slovakia, which can serve as a geographical basis for further research.
\end{abstract}

Keywords: urban tourism, accommodation establishments, tourism performance, spatial differentiation, typification

\section{Introduction}

In the present, urban tourism represents an attractive type of tourism with an important position in almost all countries of the world. Urban tourism has some highly specific characteristics and attributes. It is specified by concentration in urban areas (towns, resp. cities), which usually have a high number of cultural - historical and social values. These areas are usually also important centres of trade, culture and services. Urban tourism is also typical having high number of foreign tourists and with concentration in relatively small areas. The final characteristic associated with urban tourism is a high frequency of the tourists. However, this frequency is represented by significantly shorter duration of their stay compared to other types of tourism such as rural tourism, spa tourism or summer recreation.
The aim of this study is to evaluate the overall position of the cities in tourism in Slovakia and internal typification of urban tourism as one of the main types of tourism in Slovakia from geographical perspective. Data associated with the structure of accommodation capacities and the tourism performance in towns of Slovakia will be used for the evaluation. Consequently, overall attractiveness of towns and their internal typology is evaluated and internally differentiated. Both of the factors are quantified under the methodology of Vystopil, et al. (2011, 2006), Šauer, Vystoupil (2005) or Mariot (2001). Data is then compared at the level of the tourist resorts in Slovakia. The geographical analysis and subsequent formation of the typification are the main results of this study.

The analysis and typification are preceded by a brief academic overview of the general problematic, by a

A Department of Regional Geography, Planning and Protection of Landscape; Faculty of Natural Science; Comenius University in Bratislava; Slovakia; e-mail: kasagrandaa@gmail.com

B Department of Regional Economics and Administration; Faculty of Economics and Administration; Masaryk University in Brno; Czech Republic; e-mail: vyst@econ.muni.cz

* Corresponding author: Kasagranda Anton, e-mail: kasagrandaa@gmail.com 
definition of individual terms, by a characterization of methodology used in the research and typification of the resorts.

\section{Theoretical approaches}

The theoretical basis of studies deals with the research in the field of tourism and emphasizes the importance of an interdisciplinary approach (e.g. Holden, 2007; Kotler, et al., 2003; Newsome, et al., 2012; Papatheodorou, 2004; Pearce, 1992; Stabler, et al., 2010; Tribe, 1997; Zelenka, Pásková, 2002). Ritchie (2009) speaks of high complexity which he explains through the understanding of the systems and describes it as an "integrated system of elements".

For the purpose of geographical research of performance of tourism, the main focus is put on spatiality (e.g. Bučeková, 2013; Butler, 2004; Civáň, Krogmann, 2012; Gibson, 2008; Hall, Page, 2009; Krogmann, Šolcová, 2013; Vystoupil, et al., 2008; 2010). Hudman, Jackson (2003); Ritchie (2009) and Warszýnska, Jackowski (1978) consider geography of the tourism to be one of the youngest geographical disciplines and they observe the possibility of implementation of geography in relation to the study of tourism. Crouch (1999) provides examples of geographical research in the field of tourism that emphasizes the link to spatiality. Mariot (1983) sees the position of the geography of tourism in the scientific specialization that is based on his interpretation, that geography of tourism accentuates the study of the spatial aspects in close relation to landscape. According to Mariot (1983) validity and specificity of the geographical research is determined as these aspects are not considered as the core aim of research of any other scientific discipline that studies tourism. According to Vystoupil et al. (2011), geography of tourism is a field focused on studying the patterns of spatial relationship between geography of tourism and recreation on one hand and landscape on the other. Patterns and factual deployment of tourism in the regions with different spatial hierarchy. Also, the localization, selective and realization factors and the conditions for the development of tourism.

Vystoupil, et al. (2011; 2006) and Šauer, et al. (2015) claim that typification and consecutive internal identification of types (or forms) of tourism represent one of the main tasks of geography of tourism and it is often associated with the subsequent regionalization (or other form of hierarchization). Other authors (e.g. Havrlant, 2007; Kopšo, 1992; Kulla, 2011; 2007; Otrubová, 1996; 1991; Šprincová, 1983; 1977) confirm this hypothesis and agree that in its relation to tourism, geography should monitor and analyse primarily its spatial attributes and regularities and should participate in its consecutive organization.

\section{Evaluation of urban tourism}

It is important to understand that in quantification of the individual types of tourism, there is no clear boundary between them. On the contrary, tourist motivations are naturally overlapping significantly. Generally, if the region has several favourable conditions, it will be qualitatively characterized as a tourist resort attractive from the perspective of several types of tourism. According to Mariot (2001) or Vystoupil et al. $(2006,2011)$ the term "tourist resort" is applicable to every administrative unit (municipality, town) with the presence of collective accommodation establishments with bed capacities. Municipalities with the town (resp. city) status are classified as urban tourist resorts.

The main frame of realization conditions is the number of bed capacities in collective accommodation establishments. This number is quantified according to the methodology of Vystoupil, et al. (2011; 2006) and Šauer, et al. (2015) or Šauer, Vystoupil (2005). In many studies (e.g. Butler, 2004; Crouch, 1999; Franke, et al., 2012; Gibson, 2008; Gúčik, 2010, Lew, 2001; Nemčanský, 1999) the number of bed capacities is considered to be one of the core attributes of the basic infrastructure of tourism. Bed capacities constitute significant limiting factor for the development of tourism. Consequently, tourist traffic in these establishments is quantified and evaluated. In this study, the analysis is able to be conducted because of the manifestation of supply and demand that is easily quantifiable. A similar method for the analysis of supply and especially demand is used also by other authors (e.g. Baláž, 1995; Bučeková, 2001; Cákoci, 2013; Kasagranda, 2015a; 2015b; Mariot, 2001; Popp, 2011).

Several Slovak authors dedicated their research to the analysis of tourism of Slovakia within the last 10 years (Švajdová, 2009; Bárta, 2008; Dvořáková, et al., 2012; and partially also Šenková, 2013). Švajdová (2009) tried to define Slovakia as a tourist destination of urban tourism in her thesis. This study was specifically focused on a regional geographical analysis of 27 historical sites which were in the "Association of Historic Towns and Municipalities of Slovakia" at the time. These 27 sites were divided into three categories, represented by towns of regional, national or international importance. According to the methodology of Švajdová (2009), there are three historic towns of an international importance (Bratislava, Bardejov, Košice), 17 towns of a national importance (Banská Bystrica, Banská Štiavnica, Kežmarok, Kremnica, Levoča, Liptovský Mikuláš, Martin, Nitra, Poprad, Prešov, Ružomberok, Spišské Podhradie, Stará Lubovňa, Trenčín, Trnava, Zvolen, Žilina) and 7 towns of a local importance (Komárno, Podolínec, 
Rimavská Sobota, Rožňava, Spišská Nová Ves a Svätý Jur) located in Slovakia. The remaining 110 towns, however, were not evaluated in this study.

\section{Methodology}

Studies of Ashworth (2009); Ashworth, Page (2011); Dumbrovská, Fialová (2014); Popp (2011); Simpson (1999); Selby (2004), are interesting, from a methodological point of view, in the field of research of urban tourism. The analysis of localization conditions (according to the methodology of Vystoupil, et al., 2011; especially the analysis of cultural - historical conditions in a form of national cultural monument, monument reserves, conservation area, other monuments, World Heritage sites or other social or cultural conditions such as social events, important galleries, cinemas and similar) are included in the urban resorts typification. Apart from the tourist traffic and the bed capacities, special focus is put on the cultural - administrative localization conditions (their individual quantification and analysis exceeds the possibilities of this study) which are thoroughly analysed by the conditions authors mentioned above.

The methodology for quantification and differentiation of the importance of the urban tourism complies with the hypothesis of Vystoupil et al. (2006; 2011), Šauer et al. (2015), or Šauer, Vystoupil (2005). However, that does not mean this methodology is applied without any adjustments. To some extent, it is compared and adapted to the territory of Slovakia according to the methodology of Čuka, Šenková (2012) and Mariot (2001). Adjustments, however, are not significant, and are only represented by slight corrections, more precisely the adjustment of input data (e.g. disunity in the evidence of the national historic landmarks in Czech and Slovak Republic).

Several attributes are primarily monitored for the evaluation of the urban resorts quality. These include:

- the town status for the selected resorts of the urban tourism

- the presence of the cultural and historical conditions or landmarks (the most important are the World Heritage sites), which are hierarchically ranked from the most attractive to the least attractive

- the presence of monument reserve, monument zones, resp. important national monuments (under the MBoSR, 2015)

- the presence of important facilities for realization of social event (theatres, museums, galleries and the like)

- the existence of the realization conditions and potential for the tourism performance in the individual resorts (towns)
Based on the attributes listed above, urban tourism resorts are divided into five categories in a synthetic form. They are represented by an international, national, supra-regional and regional importance and the category of other towns.

In the following step the dominant function of towns in the terms of their functional use for the purpose of tourism is determined. The following categories are identified for the evaluation of their attractiveness: historic towns, spas, mountain resorts, summer resorts and other towns. According to this typification, the term "historic towns" shall be used for the towns that are characterized by a high concentration of cultural - historical landmarks and played an important role in the historical development of the region or the whole Slovakia. Primarily, the towns with World Heritage sites, historical sites or significant national cultural landmarks registered under the MBoSR (2015) were categorized as "historic towns". Functional typology of the other towns was evaluated based on the presence of any of the main localization conditions. Such typification is also called primary or secondary potential according to the methodology of Gučík (2010); Vystoupil et al. (2011); or Edwards et al. (2008). The remaining towns are categorized as "other towns".

\section{Results}

\section{Accommodation establishments} and the performance of urban tourism in Slovakia

For the potential tourists, urban resorts are attractive due to their natural attributes mentioned above. Primarily, it is the presence of the cultural - historic landmarks. Their existence is defined by their historical importance to a significant level. The other attribute (especially of the larger regional centres) is the high concentration of population, which is significantly related to their position as natural centres of trade, culture and services. This defines their attractiveness for various types of tourism such as an incentive or congress tourism, including business trips. Also, an important position of spa centres and urban mountain centres cannot be neglected.

There are 138 towns out of the total 2981 administration units in Slovakia (year 2015). According to Mariot (2001), 753 of them are defined as a resort of tourism. All 138 towns fall within the category of the urban tourist resorts. As a result, urban areas represent $18.3 \%$ of all the tourist areas in Slovakia. In terms of bed capacities in collective accommodation establishments, the share of these towns represents $42.4 \%$. Expression of this percentage in absolute number means that out of the total 197.7 thousand bed ca- 
Table 1. The number of bed capacities in collective accommodation establishments in towns of Slovakia in 2013

\begin{tabular}{|l|c|c|c|c|}
\hline \multirow{2}{*}{ Indicator } & \multicolumn{2}{|c|}{ Beds } & \multicolumn{2}{c|}{ Accommodation establishments } \\
\cline { 2 - 5 } & abs. ['000] & share [\%] & abs. ['000] & share [\%] \\
\hline Infrastructure in towns (cities)* & 91.43 & - & 1.56 & - \\
\hline Bratislava & 17.75 & - & 0.13 & - \\
\hline TOP 30 towns (cities)** & 74.1 & - & 1.1 & 39.7 \\
\hline Share towns (cities)/Slovakia & - & 37.5 & - & 8.7 \\
\hline Share Bratislava/towns (cities) & - & 21.2 & - & 69.9 \\
\hline Share TOP 30 towns (cities)/all towns (cities) & - & 81 & - & 31.6 \\
\hline Share TOP 30 towns (cities)/Slovakia & - & 37.5 & - & - \\
\hline Slovakia (total) & 197.75 & - & 3.5 & \\
\hline
\end{tabular}

*Database of the tourist traffic in towns, including the statistical data of the town of Vysoké Tatry

**TOP 30 towns were quantified based on the statistical data from the Statistical Office of Slovak Republic

Source: authors' own processing, 2015 - based on the data from the Statistical Office of Slovak Republic

pacities in Slovakia, 83.8 thousand bed capacities are concentrated in towns (Table 1). Similar distribution may be observed also in comparison of the absolute number of collective accommodation establishments. There are 3.5 thousand collective accommodation establishments located in Slovakia and 1.4 thousand of them are localized in towns. This represents $39.7 \%$. This ratio clearly expresses that collective accommodation establishments in towns have high number of bed capacities which are located mainly in the hotels of higher standards, usually with rating of $3^{*}$ or more.

Values associated with Bratislava, the capital city of Slovakia, illustrate the existence of high capacity collective accommodation establishments. Only $8.7 \%$ of collective accommodation establishments account for
$21.2 \%$ of all the bed capacities (Table 1). TOP 30 towns with the highest tourist traffic in Slovakia also clearly indicate that they represent the keystone of tourism in Slovakia (Supplement 1). Such conclusion is possible after the evaluation of their share in the bed capacities, collective accommodation establishments and overall tourist traffic. Significant bed capacities are located also in other major towns such as Košice, Žilina, Vysoké Tatry, Liptovský Mikuláš, Nitra or Pieštany (Figure 1). In some of them, it is necessary to emphasize their significant importance for the spa and wellness tourism (Pieštany, Rajecké Teplice) or winter tourism (Poprad, Vysoké Tatry).

A high percentage of $68.4 \%$ of all the collective accommodation establishment tourists were accommo-

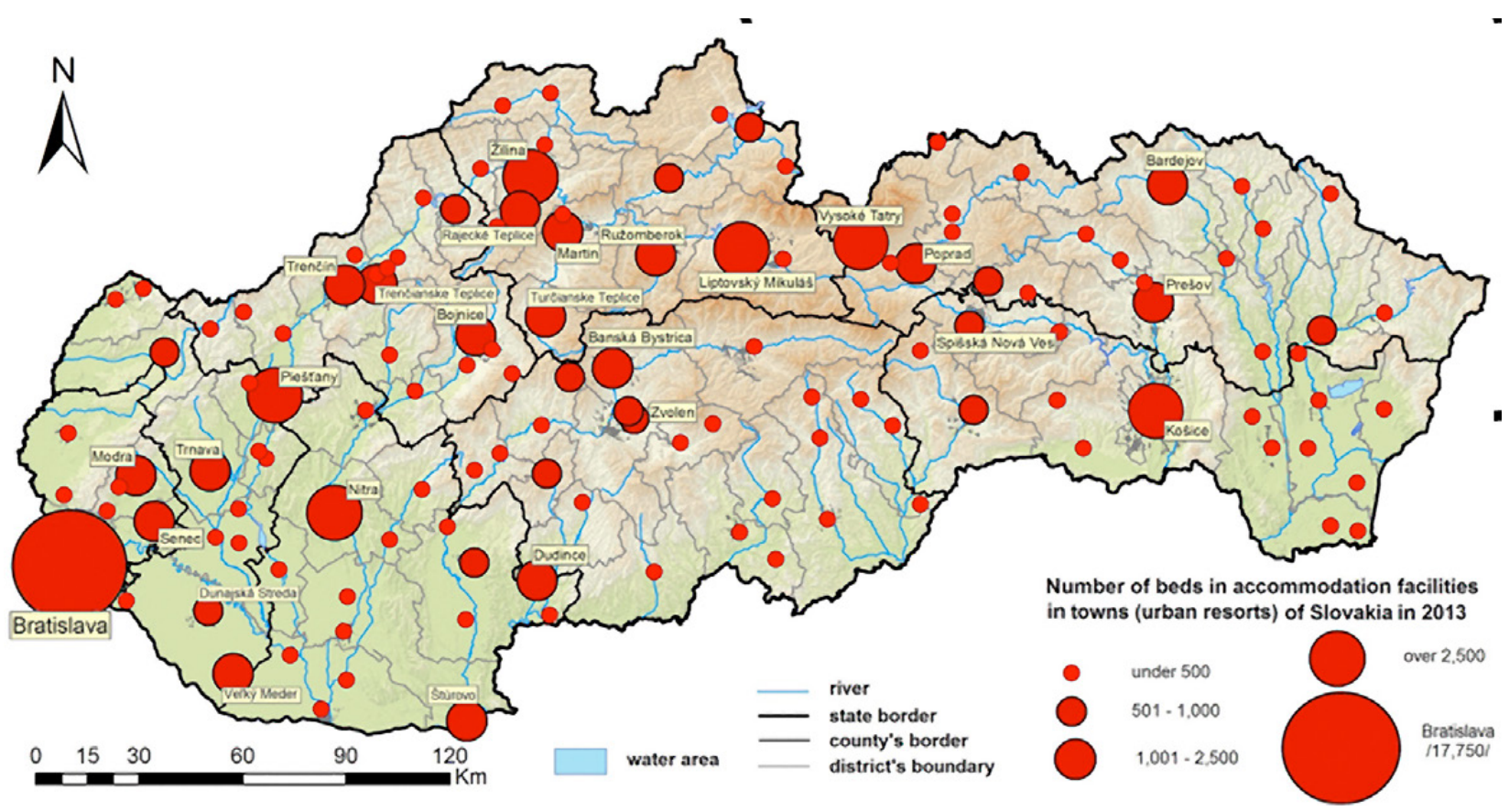

Figure 1. The number of bed capacities in collective accommodation establishments in towns of Slovakia in 2013. Source: authors' own processing, 2015 - based on the data from the Statistical Office of Slovak Republic 
dated in towns (Table 2). In case of international tourists the share is even higher and reaches $79.4 \%$. TOP 30 towns with the highest tourist traffic represent $58.5 \%$ of all the tourists of Slovakia, $71.7 \%$ in the case of international tourists (Supplement 1). The absolute dominance in this indicator may be observed in the capital city of Bratislava which is the destination of every fourth tourist. Share of the overall tourist traffic in Bratislava is $23.4 \%$ while in case of international traffic it accounts for $38.9 \%$ (Table 2). According to Dumbrovská, Fialová (2014) similar trend of dominance of the capital city in tourist traffic may be seen in various European countries (Prague, Budapest, Vienna etc.).

Tourist traffic in towns is characterized by a shorter average length of the visits. In addition to Bratisla- va, several other towns have a dominant influence in terms of bed capacities and tourist traffic in collective accommodation establishments. These are especially regional capitals such as Košice, Žilina or Nitra (Figure 2), followed by the important cultural - historic towns (Bardejov), spa resorts (Pieštany, Trenčianske Teplice, Rajecké Teplice) and tourist foothill and mountain resorts (Vysoké Tatry, Poprad).

In the case of these towns, several characteristics typical for urban tourism may be observed. The average length of the stay in towns is significantly shorter compared to other types of tourism. The structure of tourists by nationality is dominated by the international tourists and the highest tourist traffic is recorded in the most attractive cultural towns of Slovakia.

Table 2. The number of tourists and their overnight stays in towns of Slovakia in 2013

\begin{tabular}{|c|c|c|c|c|c|c|}
\hline \multirow{3}{*}{ Indicator } & \multicolumn{3}{|c|}{ Number of tourist } & \multicolumn{3}{|c|}{ Number of overnight stays } \\
\hline & total & foreign & share & total & foreign & share \\
\hline & \multicolumn{2}{|c|}{ abs. ['000] } & [\%] & \multicolumn{2}{|c|}{ abs. ['000] } & [\%] \\
\hline Visitation rate in towns (cities)* & $2,769.3$ & $1,325.3$ & 47.9 & $7,580.7$ & $3,228.3$ & 42.6 \\
\hline Bratislava & 947.7 & 647.8 & 68.3 & $1,919.8$ & $1,075.8$ & 56.0 \\
\hline TOP 30 towns (urban resorts)** & 2,402 & $1,206.48$ & 50.2 & $6,791.73$ & $2,943.33$ & 43.3 \\
\hline Share towns (urban resorts)/Slovakia & 68.4 & 79.4 & - & 66.0 & 74.4 & - \\
\hline Share Bratislava/towns (urban resorts) & 34.2 & 48.9 & - & 25.3 & 33.3 & - \\
\hline Share TOP 30 towns/all towns & 82.8 & 91 & - & 89.6 & 91.2 & - \\
\hline Share TOP 30 towns/Slovakia & 59.3 & 72.2 & - & 59.1 & 67.8 & - \\
\hline Slovakia (total) & $4,048.5$ & 1,67 & 41.2 & $11,486.6$ & 4,34 & 37.8 \\
\hline
\end{tabular}

*Database of the tourist traffic in towns, including the statistical data of the town of Vysoké Tatry

**TOP 30 towns were quantified based on the statistical data from the Statistical Office of Slovak Republic

Source: authors' own processing, 2015 - based on the data from the Statistical Office of Slovak Republic

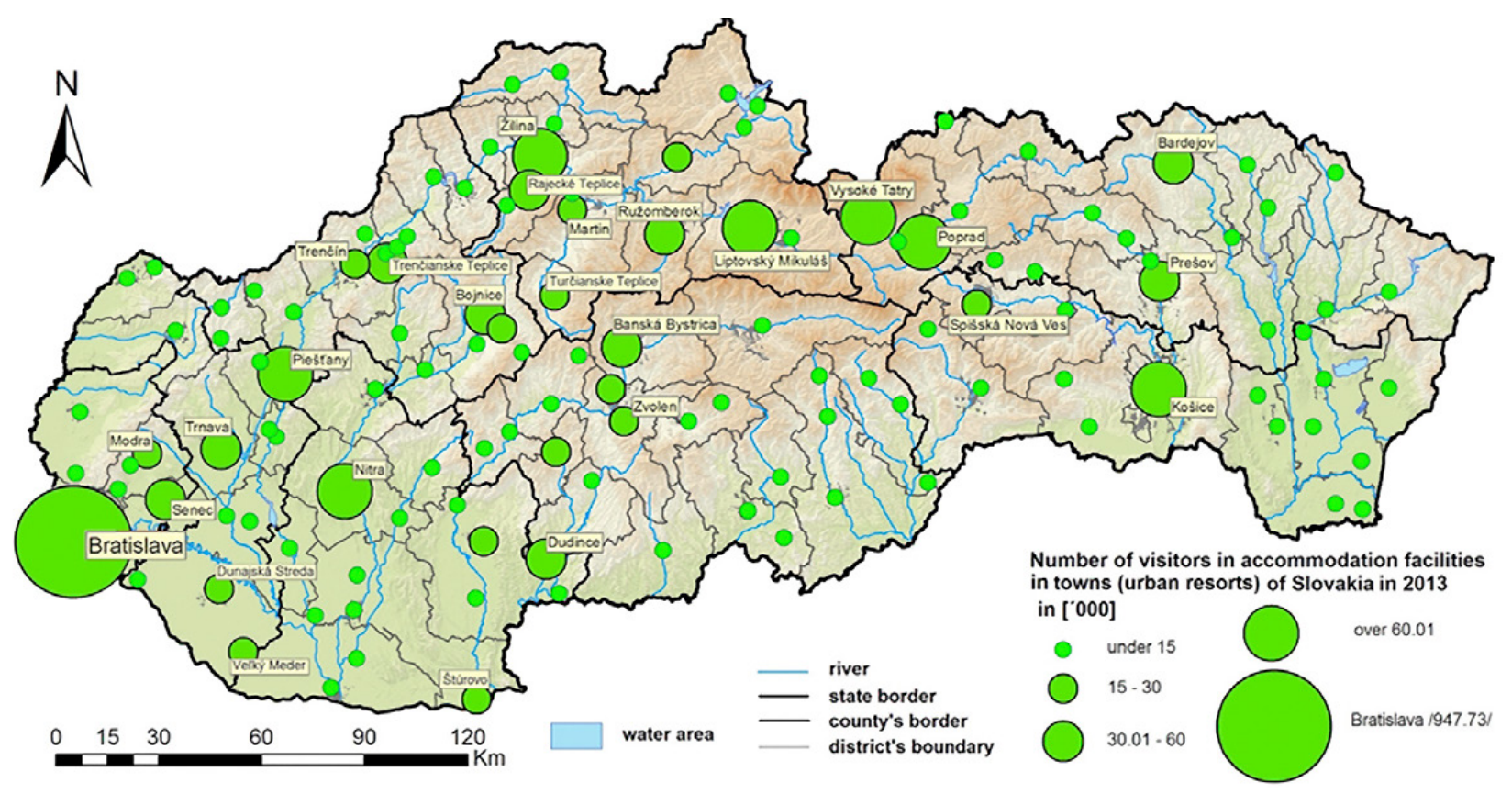

Figure 2. The number of tourists in collective accommodation establishments in towns of Slovakia in 2013 Source: authors' own processing, 2015 - based on the data from the Statistical Office of Slovak Republic 
Those are mainly the towns mentioned above such as Bratislava, Banská Bystrica, Trnava, Žilina or Nitra.

\section{Typification of the resorts}

\section{of urban tourism in Slovakia}

The first step in typification of the urban resorts was the identification of their importance and overall attractiveness (classification of the resorts based on their international, national, supra-regional or regional importance). According to the methodology of Vystoupil et al. (2011), Šauer, Vystoupil (2005), partially adjusted by Mariot (2001), all the municipalities with the town status in Slovakia were evaluated. Altogether, 138 towns in Slovakia were evaluated. The best results were achieved by Bratislava as the cultural, political, scientific, congressional and administrative centre of Slovakia. As the only town in Slovakia, Bratislava is classified as the municipality with the international importance. This is justified by all the evaluated factors.

Except for Bratislava, the most attractive category in terms of the overnight stays and overall tourist traffic is the category of municipalities with the national importance (Table 3). Along with Bratislava as the only municipality with the international importance, these are responsible for approximately $60 \%$ of the total number of the overnight stays and tourist traffic. High concentration of tourist traffic and the overnight stays clearly confirms the fact that they are the keystone and the most important resorts of the urban tourism. At the same time, these towns are exceptionally important cultural, social and economic centres. On the contrary, the resorts with the lowest tourist traffic and number of overnight stays are classified as "other towns". This category includes 76 resorts with only $9.8 \%$ share in the number of overnight stays and $10.8 \%$ share in overall tourist traffic (Table 3 ).

There are 17 towns involved in the category of the municipalities with the national importance. A significant number of them are regional capitals as the natural centres of history and culture. These are Nitra in the region of Ponitrie, Košice in Abov, Žilina and Trenčín in Považie, Trnava in Trnavsko, Banská Bystrica in Pohronie and Prešov in the region of Šariš (Figure 3). Regional capitals are followed by the spa and wellness resorts (Pieštany) or the mountain resorts such as Liptovský Mikuláš which is also an important historical centre in the region of Liptov. Sufficient tourist traffic is observed also in the resorts with World Heritage sites (Ružomberok, Bardejov, Levoča, Banská Štiavnica, Kremnica) or the important historical sites (Kežmarok). At the same time, these towns were the locations of paramount importance in the historical development of the regions, which also explains the presence of important cultural and histori- cal sites. Significant portion of the municipalities with the national importance is represented by the towns influenced by the German colonization, which had a major influence on their cultural, historical and strategical development and importance. These include Bardejov, Kežmarok, Levoča, Spišské Podhradie, Kremnica or Banská Štiavnica (Figure 3).

Category of the municipalities with the supra-regional importance is represented by 15 towns (Figure 3). These towns are characterized by relatively high tourist traffic and usually have conservation areas, historical sites or attractive and preserved national cultural landmarks. The most attractive in this category are the towns of Martin (as the centre of Matica Slovenská and high concentration of historical personalities in the past, that fundamentally shaped the national consciousness and played an important role in the formation of the Slovak nationhood), Bojnice (as a spa resort, location of the castle of Bojnice and the zoological garden), Zvolen (with an exceptionally attractive historical centre), or the resorts in the surroundings of Bratislava (Svätý Jur, Senec, Modra) which are mainly characterized by the viticulture. Several important historical towns in the region of South Slovakia such as Rožňava, Rimavská Sobota or Lučenec, are also included in this category, mainly because they used to be important aristocratic residences in the times of Kingdom of Hungary and numerous historical and cultural landscapes were preserved. One of the most significant is the town of Dudince which is an extremely popular spa destination with high tourist traffic.

Total of 29 towns in Slovakia may be classified as the municipalities with the regional importance (Figure 3). Several criteria must be met to achieve such a status. A number of the national cultural landmarks must be located in the area and at least one of them must be open to general public. Municipality also needs to have a cultural or a historical potential at the regional level (according to the MBoSR, 2015). Towns which satisfy these requirements are usually represented by at least one landscape or artefact of local importance. The most significant in this category are the towns of Bytča with its Wedding Palace, an exceptionally attractive landmark, and Rajec which is famous for its town hall and square.

The remaining 76 towns may be classified as "other towns" (Figure 3). In this category there are some important supra-regional centres such as Čadca, Nové Zámky or Považská Bystrica. These towns, however, do not play any significant role in terms of urban tourism. Most commonly, their cultural or historical role was of a minor importance and their growth only accelerated after World War II and due to massive development of the industry. As a result, these towns do not 
Table 3. Urban tourism performance and the number of overnight stays based on the typification of tourism in Slovakia

\begin{tabular}{|l|c|c|c|c|c|c|}
\hline \multirow{2}{*}{ Importance } & \multicolumn{2}{|c|}{ Number of towns (urban resorts) } & \multicolumn{2}{c|}{ Number of tourists } & \multicolumn{2}{c|}{ Number of overnight stays } \\
\cline { 2 - 3 } & \multirow{2}{*}{ Abs. } & share [\%] & \multirow{2}{*}{ Abs. ['000) } & share [\%] & \multirow{2}{*}{ Abs. ['000] } & share [\%] \\
\cline { 3 - 6 } & & SE=100\% & & SE=100\% & & SE=100\% \\
\hline International & 1 & 0.7 & 94.77 & 34.2 & $1,919.82$ & 25.3 \\
\hline National & 17 & 12.3 & 920.68 & 33.3 & $2,838.09$ & 37.5 \\
\hline Supra-regional & 15 & 10.8 & 366.6 & 13.2 & $1,115.80$ & 14.7 \\
\hline Regional & 29 & 21.1 & 233.37 & 8.4 & 963.92 & 12.7 \\
\hline Other & 76 & 55.1 & 298.57 & 10.8 & 739.55 & 9.8 \\
\hline Towns - TOTAL & 138 & 100 & $2,769.25$ & 100 & $7,580.71$ & 100 \\
\hline
\end{tabular}

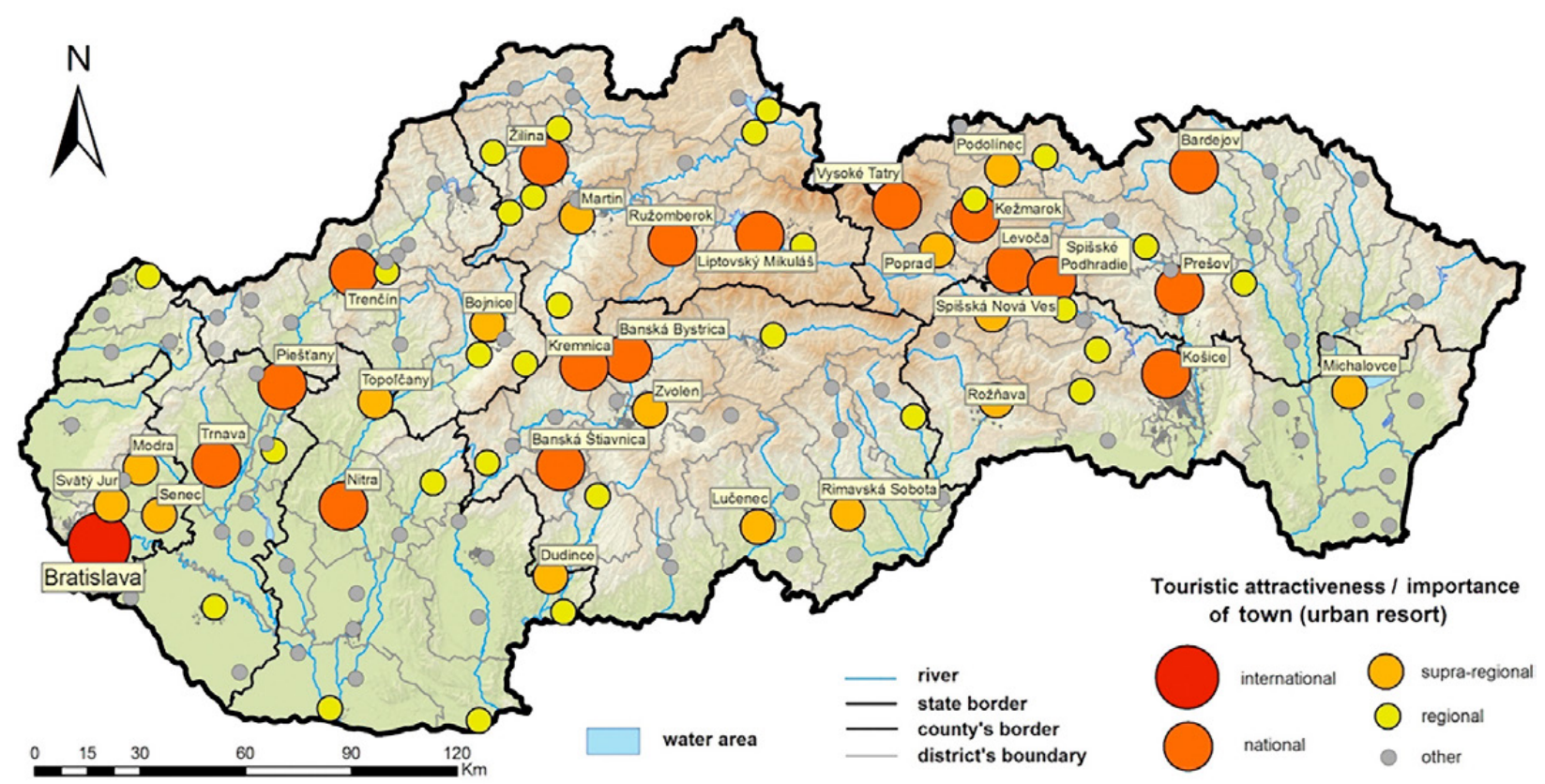

Figure 3. The attractiveness of towns of Slovakia in terms of urban tourism

Source: authors' own processing, 2015 - based on the data from the Statistical Office of Slovak Republic

have any cultural - social conditions, which are crucial for the urban tourism.

The second step in the typification of 138 urban resorts of Slovakia included in the analysis was to determine their dominant function in the terms of their functional use for the purpose of urban tourism. The following categories were identified for the evaluation of their attractiveness: historic towns, spas, mountain resorts, summer resorts and other towns (Table 4).

Analysis of the internal typology reveals that the most attractive destinations of the tourists are the historic towns, in which $53.7 \%$ of all the bed capacities of towns are situated (Table 4). Share of the tourists (61.4 $\%$ or 1.701 thousand) and the number of overnight stays ( $47.7 \%$ or 3.617 thousand) clearly demonstrate dominance of the historic towns in tourism (Table 4, Figure 4). Such cultural - historical centres in Slovakia are Bratislava in western Slovakia and Košice in eastern Slovakia along with an exceptionally impor- tant regional centres (regional capitals or the towns of Bardejov, Banská Štiavnica and Kremnica). Their spatial differentiation is evenly distributed across the whole Slovakia and these towns are the natural centres of the regions they are in. At the same time, according to MBoSR (2015) 7 out of 10 most visited objects registered as the national cultural landmarks and 9 out of 10 most visited museums in Slovakia (according to the Slovak National Museum) are located in these towns.

Spas also play an important role in urban tourism in Slovakia and are primarily represented by the towns of Pieštany, Rajecké Teplice, Turčianske Teplice or the spa resorts in Bojnice, Bardejov, Dudince and Sliač. These destinations are characterized by relatively high rates of accommodation capacities $(12.1 \%$ of bed capacities, $12.1 \%$ share of the total tourists) but especially by the high number of the overnight stays where only $12.1 \%$ of all the tourists are responsible 
Table 4. The functional typology of the towns of Slovakia in terms of tourism in 2013

\begin{tabular}{|l|c|c|c|c|c|c|c|}
\hline \multirow{2}{*}{$\begin{array}{l}\text { Type of town } \\
\text { (urban resort) }\end{array}$} & \multirow{2}{*}{$\begin{array}{c}\text { Number } \\
\text { of towns }\end{array}$} & \multicolumn{2}{|c|}{$\begin{array}{c}\text { Beds in accommodation } \\
\text { establishments }\end{array}$} & \multicolumn{2}{|c|}{ Number of tourists } & \multicolumn{3}{|c|}{$\begin{array}{c}\text { Number of overnight } \\
\text { stays }\end{array}$} \\
\cline { 3 - 9 } & & Total ['000) & share [\%] & Total ['000) & share [\%] & Total ['000) & share [\%] \\
\hline Historic towns & 27 & 49.09 & 53.7 & $1,701.22$ & 61.4 & $3,617.77$ & 47.7 \\
\hline Towns/spas & 10 & 13.96 & 15.3 & 333.83 & 12.1 & $1,996.27$ & 26.3 \\
\hline Towns/mountain resorts & 15 & 9.69 & 10.6 & 287.66 & 10.4 & 907.87 & 12.0 \\
\hline Towns/summer resorts & 22 & 5.57 & 6.1 & 140.63 & 5.1 & 330.67 & 4.4 \\
\hline Other towns & 64 & 13.12 & 14.3 & 305.9 & 11.0 & 728.13 & 9.6 \\
\hline Towns - TOTAL & 138 & 91.43 & 100.0 & $2,769.25$ & 100.0 & $7,580.71$ & 100.0 \\
\hline
\end{tabular}

Source: authors' own processing, 2015 - based on the data from the Statistical Office of Slovak Republic

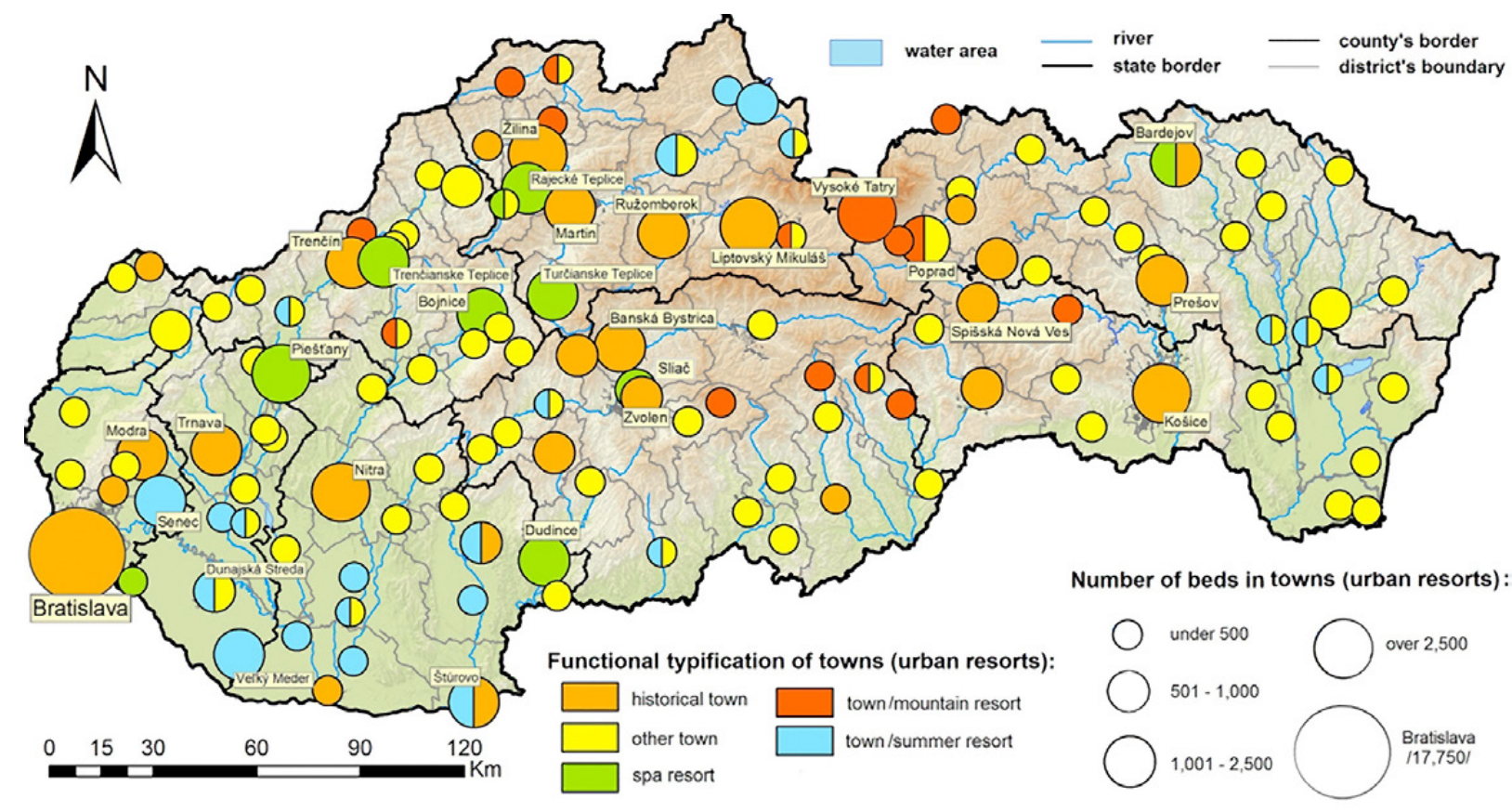

Figure 4. The functional typology of the towns of Slovakia in terms of urban tourism Source: authors' own processing, 2015 - based on the data from the Statistical Office of Slovak Republic

for $26.3 \%$ of all the overnight stays (Table 4, Figure 4). Their spatial distribution is closely associated with the natural conditions (especially in the form of abundant springs with high healing qualities) and supported by the basic and ancillary infrastructure.

Another significant group of towns in the terms of internal functional typology are mountain resorts (towns of Poprad, Vysoké Tatry or Krompachy). Share of the mountain resorts in the total number of the bed capacities represent $10.6 \%$ or 9.69 thousand (Table 4 ). Similar ratio may be observed also in the case of the total number of tourists (10.4\%) and the number of the overnight stays (12.0\%). The main characteristic of the mountain resorts is an excellent infrastructure which is closely related to winter tourism and the existence of ski resorts (Figure 4). In the most important resorts this infrastructure is used throughout the season (in winter mostly for skiing, in summer for hiking and the like). Quite understandably, the mountain re- sorts are spatially bound to the appropriate relief and most commonly, they are located in the highest and most attractive foothill and mountain areas such as in the High Tatras, Low Tatras, Great or Little Fatra.

The last group of towns specifically categorized for the purpose of this study is represented by the summer resorts that represent $6.1 \%$ or 5.51 thousand bed capacities (Table 4). These are primarily located in the area of Podunajská nížina (towns of Dunajská Streda, Nové Zámky, Senec, Sládkovičovo, Velký Meder), which have an excellent conditions for this type of tourism, especially during the summer months (Figure 4). Mountain resorts with their holiday resorts (Dolný Kubín, Tvrdošín or Trstená) also represent a significant number from this group and are attractive destinations especially for the international tourists.

The remaining towns, which were not attributed by any specific function according to the functional typification, are categorized under "other towns". None of 
these towns have a specific or prominent role in urban tourism and the total number of tourists, bed capacities or overnight stays do not reach significant values. At the same time, however, most Slovak towns are part of this category (Table 4, Figure 4).

\section{Discussion}

According to Borovský, et al (2008) one of the most important trend of Slovak tourism is development of specified types of tourism such as urban tourism, culture tourism, spa tourism, winter tourism, also rural-agroturistics, and summer, mountain and water-base tourism. New studies within current geographical research have been created in Slovakia in recent years related to quantification and identification of some of the main types of tourism (e.g. spa tourism - Matlovičová et al. 2013, water-base tourism - Lauko et al. 2015, pilgrimage tourism - Krogmann 2007, Krogman, Šolcová 2013). We can only hope that more of these kind of studies will be created.

Švajdová (2009) studied the quantification and internal typification of Slovak tourism. The author analyzed only 27 urban resorts that represents only 19.7 $\%$ of all towns' resorts in Slovakia. Her methodology identified three towns with international importance (Bardejov, Bratislava, Košice). This research analyzed all 138 urban resorts (by 2015) and identified only the capital city of Bratislava as urban resort with international importance. It is important to mention that the methodology of Švajdová (2009) uses less complex statistical basis.

Vystoupil et al. (2006, 2011), or Šauer, Vystoupil (2005) used similar methodology for the evaluation of attractiveness of the urban resorts in Czech Republic. Authors evaluated all together 308 urban resorts in Czech Republic (more than twice as compared to Slovakia), where they identified one international resort (Prague), 21 national resorts (with major role of Brno, Karlovy Vary or Františkovy Lázne) and 77 supra-regional resorts. There is huge difference (both in absolute number and share) between the number of supra-regional resorts in Czech Republic and Slovakia (77 in Czech Republic, share of 25 \% vs. 15 in Slovakia with share of $10.9 \%)$. The absolute number of towns in the categories of international (one in both Czech Republic and Slovakia) and national (21 in Czech Republic, share of $6.8 \%$ and 17 in Slovakia, share of 12.3 $\%$ resorts are comparable. However, it is considerable difference of share if both countries. Compared results are partially striking, when taking into account the size of the countries, their historical development (strong influence on development of the towns as cultural centers of regions) and their position in the central European region.
From the perspective of the urban tourism, there is an obvious dominance in the tourist performance of the capital cities, as they are cultural, political, social, scientific etc. centers of their countries. This dominance can be observed also in Bratislava. According to Dumbrovská, Fialová (2014) the same status can be observed in Prague (Czech Republic), Vienna (Austria) or Budapest (Hungary). Another typical feature of capital cities is the high number of international tourists (according to SOSR 2015 in Bratislava 68.3\% and according to CZSO $2015-87.2 \%$ in Prague).

\section{Conclusion}

Statistical indicators of the tourism performance, the number of bed capacities and accommodation capacities of the collective accommodation establishments as well as the number of the overnight stays clearly demonstrate a significant importance of urban tourism as one of the dominant types of tourism in Slovakia. Share of the urban areas in the total number of collective accommodation establishments and their bed capacities are approximately $40 \%$ and it accounts for more than $65 \%$ of the overall tourism performance. As a part of a culturally rich continent, Slovakia has some exceptionally attractive cultural - historical landmarks, which are typical for this form of tourism. In Slovakia there are several extremely valuable cultural - historical landmarks (some of which are integrated into the list of World Heritage sites) which are presently important part of cultural heritage of the country.

Bratislava, the capital city of Slovakia, is clearly the most important centre of urban tourism in Slovakia. Bratislava is the only urban resort in Slovakia classified as the town of international importance. In the European context, it is mainly characterized as an attractive part of Central Europe. Its importance is fundamentally affected by its location near the Danube with a very good accessibility to the surrounding cultural - historical areas such as Vienna, Budapest or Brno. Statistical indicators also indicate dominant position of Bratislava as the highest number of collective accommodation establishments is located in the town (it also has the highest share of both domestic and international overnight stays).

There are several other attractive urban areas important from the perspective of the urban tourism. They are represented especially by the town of Košice as an important supra-regional centre of culture, society, administration and economy of all the eastern Slovakia. Also, the regional capitals of Žilina, Prešov, Trnava, Nitra, Banská Bystrica and Trenčín and the important regional centres including historic towns which used to play major role in the development of 
Slovak regions such as Spiš (Levoča), Šariš (Bardejov), Liptov (Ružomberok, Liptovský Mikuláš), respectively the mining towns (Kremnica, Banská Bystrica) located in central Slovakia. Spatial variability of the other major urban areas is relatively high. The location of these areas is associated with the historical and social conditions such as in the case of Martin with high concentration of historical figures that shaped the national consciousness, or Modra with connection to Ludovít Štúr and Svätý Jur or Podolínec with attractive monument reserves, etc. All is closely related to historical development and specific cultural or historical references which were preserved until present day.

The most important urban areas can be typified into several major categories. The historic towns, including the regional capitals mentioned above, have the dominant position. Furhter more, there are some exceptionally important urban areas represented by the spas (Pieštany, Trenčianske Teplice, Sliač, Bojnice or Dudince), the mountain resorts (towns of Vysoké Tatry, Poprad, Dolný Kubín), the summer resorts (located primarily in the territory of Podunajská nížina -Dunajská Streda, Nové Zámky, Vel'ký Meder, Východoslovenská nížina -Michalovce), or are situated in foothill and mountain areas (Dolný Kubín, Tvrdošín or Trstená). These urban resorts significantly increase the attractiveness of the territory.

The structural funds of the European Union still represent a considerable source of income for the restoration of damaged or poorly maintained landmarks. As these landmarks significantly increase attractiveness of the regions, the structural funds become very important. Explanation of the past and future implementation of the European funds represents a complex problem that exceeds the focus of this study. The effectivity of the implementation has (with high probability) not met the expected numbers and will not meet the expected numbers in the near future. This issue is also the aim of research of Rajčáková, Švecová (2015; 2014; 2013). It is questionable how will the position of urban areas look like in the near future, in the system of Slovak tourism. Better international promotion may represent a major breakthrough in terms of the tourism performance or the importance of urban areas in Slovakia.

Finally, it can be conclude that the geographical quantification of urban tourism, its hierarchy and functional typification is an important tool for cartographic interpretation of spatial organization of tourism at regional, national and international comparisons. Mainly, the definition of tourist resorts (especially urban resorts), subsequent determination of their attractiveness and definition of the main functions (typification) allowed (and still allows) comparison of position of tourism in different regions. It also allows monitoring of the trends over time (mainly changes in functionality, development of tourist infrastructure, etc.).

\section{Acknowledgment}

The research was funded through the project VEGA 1/0540/16 Social, Economic and Environmental Determinants of Development and Transformation of the Regions: The Geographic Approach, as well as with support of project UK/2/2016 Evaluation and Spatial Differentiation of Tourism in Slovakia.

\section{References}

Ashworth, G. J. 2009. Questioning the Urban in Urban Tourism. In: Maciocco, G. - Sereli, S. (Eds.). Enhancing the Cities: New Perspectives for Tourism and Leisure. Urban Landscape and Perspectives. London: Springer. 207-220 pp.

Ashworth, G.J., Page, S.J. 2011. Urban Tourism Research: Recent Progress and Current Paradoxes. Tourism Management 32,1, 1-15.

Bárta, V. 2008. Jewelleries of Slovakia. Bratislava: AB Art press. 1. eds. 64 pp. (in Slovak)

Baláž, V. 1995. Five Years of Economic Transition in Slovak Tourism: Successes and Shortcomings. Tourism Management 16,2, 143-159.

Borovský, J., Smolková, E., Niňajová, I. 2008. Tourism - Trends and Perspectives. 1. ed. Bratislava: Iura edition, s.r.o., 280 pp. (in Slovak)

Bučeková, I. 2013. Bratislava-Most Important Centre of Tourism in Slovakia. In Buček, J., Korec, P. (eds.): Modern Human Geography of Bratislava City: Spatial Structures, Networks and Processes. Bratislava: Univerzita Komenského, 171-193 pp. (in Slovak)

Bučeková, I. 2001. Model of Hotel Localization in the Territory of Large Cities - Example of Bratislava. Ekonomická revue cestovného ruchu/Economical Revue of Tourism 34,1, 17-27. (in Slovak with English summary)

Butler, R.W. 2004. Geographical research on Tourism, Recreation and Leisure: Origins, Eras and Directions. Tourism Geographies 6,2. 143-162.

Cákoci, R. 2013. Tourism in Slovakia. In: Lauko, V. et al. Geography of Slovak Republic - Human Geography. Bratislava. Geografika, 214-253 pp.

Civáň, M., Krogmann, A. 2012. Shopping Tourism Between Slovakia and Austria. Geografické Informácie/Geographical Information 16,1, 42-50 pp. (in Slovak with English summary)

Crouch, D. (eds.) 1999. Leisure/tourism geographies: practices and geographical knowledge. London: Routledge. 305 pp.

CZSO - Czech Statistical Office 2015. Visitors and number of overnight stays in accommoda- 
tion establishments [online]. c2015. [cit. 201510-05] available online: https://vdb.czso.cz/ vdbvo2 $/$ faces $/$ index.jsf?page $=$ vystup-objekt parametry\&evo $=\&$ pvo $=$ CRUo 4 \&verze $=-1 \&$ nahled $=\mathrm{N} \& \mathrm{sp}=\mathrm{A} \&$ skupId $=1006 \& \mathrm{katalog}=31743 \&$ udIdent $=\& \mathrm{zo}=\mathrm{N} \& \mathrm{z}=\mathrm{T}$ (in Czech)

Čuka, P., Šenková, A. 2012. Geography of Tourism of Slovakia. In: Widawski, J. - Wyrzykowski, K. ed. 2012. Geography of Tourism of Central and Eastern Europe Countries. Wroclaw: University of Wroclaw, 381-406 pp.

Dumbrovská, V., Fialová, D. 2014. Tourist Intensity in Capital Cities in Central Europe: Comparative Analysis of Tourism in Prague, Vienna and Budapest. Czech Journal of Tourism 3,1, 5-26.

Dvořáková, V., Kollár, D., Oršulová, J. 2012. Historical Towns in Slovakia. Bratislava: Slovart. 352 pp. (in Slovak)

Edwards, D., Griffin, T., Hayllar, B. 2008. Urban Tourism Research: Developing an Agenda. Annals of Tourism Research 25,4, 1035-1052.

Franke, A., Attl, P., Holešinská, A., Nejdl, K., Petř́čková, L., Piteková, L., Semeniuk, P., Studnička, P., Šauer, M., Vlček, J., Vogelová, M., Vystoupil, J., Zelenka, J. 2012. Reduction of Regional Disparities through the Development of Rural Tourism. Praha: Wolters Kluwer ČR. 312 pp. (in Czech)

Gibson, C. 2008. Locating Geography of Tourism. Progress in Human Geography 32,3, 407-422.

Gúčik, M. 2010. Tourism - Introduction to Study. Banská Bystrica: Slovak-Swiss Tourism. 307 pp. (in Slovak)

Hall, C.M., Page, S.J. 2009. Progress in Tourism Management: From the geography of tourism to geographies of tourism. Tourism Management 30,1, 3-16.

Havrlant, J. 2007. Geography of Tourism II. - Geography of Tourism of Czech Republic. Ostrava: Ostravská univerzita. (in Czech)

Holden, A. 2007. Environment and Tourism. New York: Taylor \& Francis, 2007. 296 pp.

Hudman, L.E, Jackson, R.H. 2003. Geography of Travel Tourism, New York: Engage Learning, 534 pp.

Kasagranda, A. 2015a. Departure /Foreign Passive/ tourism of citizens of Slovak Republic. Studia Turistica 6,1, 27-39. (in Slovak)

Kasagranda, A. 2015b. Spatial Differentiation of Tourism Performance of Slovakia and Its Specificities. Czech Journal of Tourism 4,1, 58-74. DOI: 10.1515/ cjot-2015-0004

Kopšo, E. 1992. Geography of Tourism. Bratislava: SPN. 328 pp. (in Slovak)

Kotler, P. Bowen, J.T., Makens, J.C. 2010. Marketing for Hospitality and Tourism. 5th Ed. New York: Prentice Hall, 683 pp.
Krogmann, A. 2007. Religious Tourism in District of Nitra. Nitra: Constantine the Philosopher University. 100 pp. (in Slovak)

Krogmann, A., Šolcová, L. 2013. Religiosity and its Potential for Tourism Development in the Nitra Region. Studia Turistica 4,1, 13-18. (in Slovak)

Kulla, M., 2011. Selected Aspects of Tourism in Zemplínska Š́rava. Geographia Cassoviensis 5,1, 73-78. (in Slovak with English summary)

Kulla, M. 2007. Characteristics of Selected Forms of Tourism in Košice Town and Its Surroundings. Geographia Cassoviensis 1,1, 101-112. (in Slovak with English summary)

Lauko, V., Španihel, M., Polčák, N. 2015. Analysis of Climatic Conditions for Summer Recreation in Tourism Regions of Slovakia. in: College of Polytechnics Jihlava: Proceedings of the 1oth International Conference - current issues in tourism. 237-248. (in Slovak)

Lew, A.A. 2001. Defining a geography of tourism. Tourism Geographies 3,1, 105-114.

Matlovičová K., Kolesarová J. Židová A. 2013. Slovak spas in the context of change - current conditions, issues and challenges, in Dej M., Huculak M., Jarczewski W. (Eds). Recreational use of geothermal water in Visegrad Group countries. Kraków, 161-173. (in Slovak)

Mariot, P. 2001. Contribution to Typification of Centres of Tourism. Geografický časopis/Geographical journal 53,4, 307-319. (in Slovak with English summary)

Mariot, P. 1983. Geography of Tourism. $1^{\text {st }}$ ed. Bratislava: Slovenská akadémia vied. 252 pp. (in Slovak)

Nemčanský, M. 1999. The Tourism Industry - selected chapters, Part I. 1. Eds. Opava: Slezská univerzita. 278 pp. (in Czech)

Newsome, D., Moore, S.A., Dowling, R.K. 2012. Natural Area Tourism - Ecology, Impacts and Management. 2nd ed. Bristol: Channel view publications, $457 \mathrm{pp}$.

Otrubová, E. 1996. Human Geography II - (Foreign Trade, Tourism). Bratislava: Univerzita Komenského v Bratislave, 146 pp. (in Slovak)

Otrubová, E. 1991. Socio-Economic geography II (Foreign Trade, Tourism). Bratislava: Comenius University. 137 pp. (in Slovak)

MBoSR - The Monuments Board of Slovak Republic 2015. Register of Monument zones and reservations in Slovakia, resp. Register of Selected Cultural Monuments [online]. c2015. [Cited 2015-10-30]. http:// www.pamiatky.sk/sk/page/register-pamiatkovychrezervacii (in Slovak)

Papatheodorou, A. 2004. Exploring the evolution of tourism resorts. Annals of tourism research 31,1, 219-237. 
Pearce, D.G. 1992. Tourism Organizations. Harlow: Longman Group. UK. Ltd. 219 pp.

Popp, M. 2011. Positive and Negative Urban Tourist Crowding: Florence, Italy. Tourism Geographies: An International Journal of Tourism Space, Place and Environment 14,1, 50-72.

Rajčáková, E., Švecová, A. 2015. Regional Disparities in Slovakia in Contents of Cohesion Policy in EÚ 2007-2013. Bratislava: Comenius University. 114 pp. (in Slovak)

Rajčáková, E., Švecová, A. 2014. Social Inclusion -Regional Disparities in Context of Cohesion Policy of EÚ 2007-2013 in Slovakia. In: Lauko, V. et al. Geographical Dimensions of Slovakia. Bratislava: Comenius University, 219-255 pp. (in Slovak)

Rajčáková, E., Švecová, A. 2013. Cross-Border Cooperation in Slovak-Czech Border Region under EU Programmes. European Countryside 5,2, 133-145.

Ritchie, B. 2009. Crisis and disaster management for tourism. Bristol: Channel View Publications. 296 pp.

Selby, M. 2004. Understanding Urban Tourism: Image, Culture and Experience. London: Tauris. $228 \mathrm{pp}$.

Simpson, F. 1999. Tourism Impact in the Historic Centre of Prague: Resident and Visitor Perceptions of the Historic Built Environment. The Geographical Journal 165,2, 173-183.

Stabler, M., Papatheodorou, A., Sinclair, M. T. 2010. The economics of tourism. London: Routledge. 506 pp.

SNM - Slovak National Museum 2015. Annual reports of museums of the Slovak Republic [online]. c2015. [Cited 2015-10-30]. http://www.snm.sk/?vyrocnespravy-muzei-sr (in Slovak)

SOSR - Statistical Office of Slovak Republic 2015. Internal Materials Obtained by Personal Communication (in Slovak)

Šauer, M., Vystoupil, J., Holešinská, A., Palatková, M., Pásková, M., Zelenka, J., Fialová, D., Vágner, J., Halámek, P., Repík, O., Petr. O., 2015. Tourism - textbooks. 1st ed. Brno: Masaryk University. 477 pp. (in Czech)

Šauer, M., Vystoupil, J. 2005. Urban Tourism in Czech Republic. In: Wyrzykowski, J. (eds.). (2005). Conditions of The Foreign Tourism Development in Cen- tral and Eastern Europe: Urban tourism - present state and development perspectvies 8, 129-136.

Šenková, A. 2013. Analysis of Development of Tourism and Hotel Business in Slovakia after year 1989. Mladá veda/Young Science 1,2, 29-38. (in Slovak)

Šprincová, S. 1983. Geography of Tourism and Recreation in ČSSR (Development of Thematic Focus). In: Střída, M. (ed.): Geographical Research in Czechoslovak Academy of Science 1952-1982. Scientific Symposium - Conference Proceeding. Libice: Geografický ústav, 218-223 pp. (in Czech)

Šprincová, S. 1977. Development of Geography of Tourism in Poland and Czechoslovakia. Economical and Geographical Studies - Studia Geographica 61, 109-117. (in Czech)

Švajdová, A. 2009. Slovakia as a Touristic Destination - Historical Towns/Cities (Regional Geographical Analysis). Diploma Thesis. Brno: Masaryk University, 104 pp. (in Slovak)

Tribe, J. 1997. The discipline of tourism. Annals of tourism Research 24,3, 638-657.

Vystoupil, J., Holešinská, A., Kunc, J., Seidenglanz, D., Šauer, M., Tonev, P. 2011. Geography of Tourism of Czech Republic. Plzeň: ALEŠ. 315 pp. (in Czech)

Vystoupil, J., Šauer, M., Studnička, P. 2010. Analysis of Development Support of Tourism in Czech Republic Throw Regional Operational Programme in a Period of 2007-2010. Czech Hospitality and Tourism Papers 6,3, 24-48. (in Czech)

Vystoupil, J., Holešinská, A., Kunc, J., Maryáš, J., Seidenglanz, D., Šauer, M., Tonev, P., Viturka, M. 2006. Atlas of Tourism of Czech Republic. Praha: Ministerstvo pro místní rozvoj ČR. 158 pp. (in Czech)

Vystoupil, J. 2008. Geography of Tourism. In: Toušek, V. - Kunc, J - Vystoupil, J. Economical and Sociological Geography. Plzeň: vyd. Aleš Čenek. 411 pp. (in Czech)

Warszýnska, J., Jackowski, A. 1978. Fundamentals of Geography of Tourism. Varšava: Państ. Wydaw. Naukowe. 331 pp. (in Polish)

Zelenka, J., Pásková, M. 2002. Explanatory Dictionary of Tourism. Praha: Ministerstvo místního rozvoje. 448 pp. (in Czech) 
Urban tourism in Slovakia - its quantification,

spatial differentiation and typification

Supplement 1. TOP 30 selected towns (urban resorts) in Slovakia - the number of accommodation establishments, tourist traffic and overnight stays

\begin{tabular}{|c|c|c|c|c|c|c|c|c|c|}
\hline \multirow{2}{*}{$\begin{array}{l}\text { Town } \\
\text { (urban resort) }\end{array}$} & \multicolumn{3}{|c|}{ Accommodation establishments } & \multicolumn{3}{|c|}{ Tourists } & \multicolumn{3}{|c|}{ Overnight stays } \\
\hline & abs. & rooms & beds & total & home & foreign & total & home & foreign \\
\hline Bratislava & 128 & 8,234 & 17,750 & 947,730 & 299,970 & 647,760 & $1,919,823$ & 844,036 & $1,075,787$ \\
\hline Vysoké Tatry & 115 & 2,658 & 7,092 & 214,839 & 141,684 & 73,155 & 756,051 & 500,037 & 256,014 \\
\hline Košice & 67 & 1,958 & 4,380 & 151,657 & 84,498 & 67,159 & 285,736 & 151,819 & 133,917 \\
\hline Pieštany & 38 & 2,050 & 4,218 & 88,846 & 47,707 & 41,139 & 576,803 & 228,642 & 348,161 \\
\hline Poprad & 41 & 809 & 1,969 & 74,751 & 30,140 & 44,611 & 162,166 & 52,975 & 109,191 \\
\hline Nitra & 36 & 1,309 & 2,795 & 73,164 & 45,813 & 27,351 & 171,019 & 110,498 & 60,521 \\
\hline Žilina & 34 & 1,110 & 2,522 & 71,531 & 45,567 & 25,964 & 146,035 & 87,254 & 58,781 \\
\hline Liptovský Mikuláš & 82 & 809 & 2,609 & 65,838 & 25,379 & 40,459 & 184,483 & 54,698 & 129,785 \\
\hline Senec & 28 & 543 & 1,351 & 59,307 & 33,731 & 25,576 & 129,663 & 60,047 & 69,616 \\
\hline Dudince & 16 & 866 & 1,697 & 54,326 & 45,619 & 8,707 & 310,963 & 255,067 & 55,896 \\
\hline Trenčianske Teplice & 22 & 998 & 1,885 & 48,497 & 36,106 & 12,391 & 309,345 & 241,351 & 67,994 \\
\hline Trnava & 29 & 900 & 2,279 & 41,603 & 24,169 & 17,434 & 100,040 & 62,303 & 37,737 \\
\hline Banská Bystrica & 36 & 809 & 1,779 & 39,970 & 26,677 & 13,293 & 78,756 & 56,205 & 22,551 \\
\hline Rajecké Teplice & 22 & 472 & 1,046 & 39,966 & 23,318 & 16,648 & 139,573 & 66,840 & 72,733 \\
\hline Bardejov & 31 & 901 & 1,876 & 38,944 & 30,951 & 7,993 & 263,249 & 236,346 & 26,903 \\
\hline Prešov & 34 & 752 & 1,875 & 34,347 & 21,197 & 13,150 & 67,662 & 33,853 & 33,809 \\
\hline Ružomberok & 34 & 616 & 1,523 & 33,732 & 24,026 & 9,706 & 68,816 & 49,812 & 19,004 \\
\hline Bojnice & 28 & 862 & 1,940 & 31,393 & 22,732 & 8,661 & 233,172 & 176,268 & 56,904 \\
\hline Štúrovo & 38 & 477 & 1,679 & 29,752 & 19,336 & 10,416 & 97,745 & 58,892 & 38,853 \\
\hline Dunajská Streda & 20 & 235 & 602 & 27,784 & 13,255 & 14,529 & 59,329 & 22,519 & 36,810 \\
\hline Trenčín & 27 & 465 & 1,193 & 27,352 & 16,341 & 11,011 & 58,189 & 36,443 & 21,746 \\
\hline Turčianske Teplice & 14 & 561 & 1,164 & 27,225 & 22,215 & 5,010 & 223,831 & 185,426 & 38,405 \\
\hline Zvolen & 17 & 405 & 922 & 27,123 & 18,761 & 8,362 & 44,675 & 28,264 & 16,411 \\
\hline Martin & 17 & 519 & 1,469 & 23,850 & 15,462 & 8,388 & 53,508 & 32,203 & 21,305 \\
\hline Modra & 21 & 408 & 1,015 & 21,164 & 17,571 & 3,593 & 38,026 & 29,518 & 8,508 \\
\hline Vel'ký Meder & 48 & 506 & 1,368 & 19,391 & 5,362 & 14,029 & 70,695 & 18,894 & 51,801 \\
\hline Dolný Kubín & 19 & 330 & 904 & 19,333 & 10,201 & 9,132 & 42,214 & 25,699 & 16,515 \\
\hline Spišská Nová Ves & 10 & 246 & 698 & 17,769 & 12,027 & 5,742 & 35,751 & 21,024 & 14,727 \\
\hline Levice & 13 & 332 & 867 & 17,421 & 9,863 & 7,558 & 42,369 & 21,738 & 20,631 \\
\hline Sliač & 6 & 343 & 684 & 16,707 & 14,115 & 2,592 & 86,831 & 76,932 & 9,899 \\
\hline Banská Štiavnica & 30 & 335 & 900 & 16,694 & 11,729 & 4,965 & 35,212 & 22,795 & 12,417 \\
\hline $\begin{array}{l}\text { together } \\
\text { TOP } 30 \text { town }\end{array}$ & 1,101 & 31,818 & 74,051 & $2,402,006$ & $1,195,522$ & $1,206,484$ & $6,791,730$ & $3,848,398$ & $2,943,332$ \\
\hline $\begin{array}{l}\text { together towns } \\
\text { (urban resorts) }\end{array}$ & 1,575 & 38,664 & 91,426 & $2,769,246$ & $1,443,949$ & $1,325,297$ & $7,580,709$ & $4,352,452$ & $3,228,257$ \\
\hline Slovakia total & 3,485 & 56,104 & 197,747 & $4,048,505$ & $2,378,557$ & $1,669,948$ & $11,486,571$ & $7,146,562$ & $4,340,009$ \\
\hline
\end{tabular}

Source: authors' own processing, 2015 - based on the data from the Statistical Office of Slovak Republic 